\title{
FREQUENCY AND DISTRIBUTION OF BLOOD GROUPS AMONG MEDICAL STUDENTS IN A TERTIARY CARE HOSPITAL OF NORTH EAST INDIA
}

\author{
Jyoti Prasad Deori', Sujoy Kumar De ${ }^{2}$ \\ ${ }^{1}$ Assistant Professor, Department of Physiology, Silchar Medical College, Silchar, Assam. \\ ${ }^{2}$ Post Graduate Resident, Department of Pathology, S. S. Institute of Medical Sciences and Research Centre, Davangere.
}

\section{ABSTRACT}

\section{BACKGROUND}

The $\mathrm{ABO}$ and Rhesus (Rh) blood group systems are clinically most important compared to other systems. Acquaintance of the geographical and ethnicity wise distribution of $\mathrm{ABO}$ and $\mathrm{Rh}$ blood group is necessary for operative management of blood banks, transfusion medicine and genetic research.

\section{AIMS}

This study was designed to collect data on $\mathrm{ABO}$ and Rh distribution among Assamese and its comparison with similar Indian studies.

\section{METHODS}

Study was accomplished on 84 first year local Assamese medical students in the Physiology Department of Silchar Medical College, Assam. The blood samples were collected by finger prick method. ABO blood grouping and Rhesus factors (Rh) typing were decided by glass slide method.

\section{RESULTS}

Among Assamese medical students, the maximum prevalent blood group was A (33.33\%) followed by B (30.95\%), 0 (25\%) and $\mathrm{AB}$ (10.72\%); 97.62\% students were Rh positive.

\section{CONCLUSION}

The study authorises that blood group A is the commonest of the ABO blood group system in the Assamese population studied and the $\mathrm{AB}$ blood group is the least. Rhesus positive is much commoner than Rhesus negative in Assam.

\section{KEYWORDS}

ABO Blood Groups, Rh, Assamese, Medical Students.

HOW TO CITE THIS ARTICLE: Deori JP, De SK. Frequency and distribution of blood groups among medical students in a tertiary care hospital of north east India. J. Evolution Med. Dent. Sci. 2016;5(32):1704-1706, DOI: 10.14260/jemds/2016/401

\section{INTRODUCTION}

$\mathrm{ABO}$ and Rhesus (Rh) blood group systems till today remain clinically most important in spite of being identification of around twenty nine blood group systems, enumerated by International Society of Blood Transfusion. In 1900, Karl Landsteiner detected the human ABO blood group. ${ }^{1}$ The $\mathrm{Rh}$ blood group system was discovered during 1939-1940 by Landsteiner, Weiner, Levine and Stetson, clarifying the basis of many unpredicted transfusion reactions. In 1945, Coombs, Mourant and Race described the use of antihuman globulin (Coombs test) for incomplete antibodies. ${ }^{2}$ Later, these two systems have substantiated to be the most important in transfusion medicine. Today, the requirement for blood group frequency and prevalence studies is multiuse, besides their importance in relative to blood transfusion and organ transplantation.

\section{Financial or Other, Competing Interest: None.}

Submission 04-03-2016, Peer Review 01-04-2016,

Acceptance 06-04-2016, Published 19-04-2016.

Corresponding Author:

Dr. Jyoti Prasad Deori,

Assistant Professor

Department of Physiology,

Silchar Medical College,

Silchar-788014, Assam, India.

E-mail:j_deori@rediffmail.com

DOI: $10.14260 /$ jemds/2016/401
Blood group antigens can also be applied in genetic research, forensic pathology, anthropology and ancestral evolution of human. ${ }^{3}$

Nowadays, the ABO blood groups display an extensive geographical variation and vary noticeably both within and among ethnic groups. Hence, the knowledge of blood group distribution in diverse populace is of importance in health care and transfusion practices. ${ }^{4}$

Knowledge of blood group distribution is vital for clinical studies, for dependable geographical information and it will aid a lot in population genetic studies as access to safe supply of blood will help significantly in reducing the preventable deaths. Therefore, it is relevant to have statistics on the frequency distribution of these blood groups in any population group.

\section{MATERIAL AND METHODS}

This cross sectional observational study conducted over Assamese students at the Department of Physiology of Silchar Medical College, Assam, in the month of December 2015. After prior informed consent and institutional ethical clearance samples were collected from one hundred medical students, studying first professional MBBS. Among the students, 84\% were from various territories of Assam, i.e. Barrack valley, Lower Assam, Upper Assam; and the rest 16\% students were from various other states of India, i.e. West Bengal, Bihar and Meghalaya, etc. 
Students outside domicile of Assam were excluded from this study. Under a septic preventive measure by finger prick method, non-haemolysed blood samples were collected and emergency based glass slide or tile was used for identification of ABO blood grouping and Rhesus factors (Rh) typing. Commercially available Tulip diagnostics Eryscreen antisera A, antisera $B$ and antisera D kits were used for this study. Blood samples were treated with anti-A, anti-B and anti-D antisera over glass slides and mixed uniformly over an area of $2.5 \mathrm{~cm}$ by mixing stick. After two minutes of gentle rocking samples were observed for agglutination, both macroscopically and microscopically. ${ }^{5}$

Following Landsteiner laws blood groups and IgG antibodies of Rh system of those students were identified and relevant data were entered into Microsoft Excel sheet 2013 and tabulated with graphical representation.

\section{RESULTS}

Out of eighty four Assamese medical students, 47 (55.95\%) were males and $37(44.05 \%)$ were females with mean \pm SD age of $18.95 \pm 0.85$ years. In our study among 84 Assamese students most prevalent blood group was A, 28 cases (33.33\%) followed by $\mathrm{B}$ in 26 cases (30.95\%), 0 in 21 (25\%) cases and AB in 9 cases $(10.72 \%)$.

\begin{tabular}{|c|c|c|c|c|c|c|c|}
\hline Blood & \multirow{2}{*}{ Male (n=47) } & Rh pos & Rh neg & Female (n=37) & Rh pos & Rh neg & Total \\
\cline { 1 - 6 } Groups & 16 & 15 & 1 & 12 & 11 & 1 & 28 \\
\hline A & 14 & 14 & 0 & 12 & 11 & 1 & 26 \\
\hline AB & 6 & 6 & 0 & 3 & 3 & 0 & 9 \\
\hline O & 11 & 11 & 0 & 10 & 10 & 0 & 21 \\
\hline \multicolumn{7}{|l}{ Table 1: Frequency Distribution of Different Blood Groups among Medical Students from Assam } \\
\hline
\end{tabular}

Among 84 Assamese students, 82 (97.62\%) showed Rh positive blood group. In Rh-positive cases, among $\mathrm{AB}$ and $\mathrm{O}$ blood group all were Rh-positive followed by $B(96.15 \%, n=25)$ and $\mathrm{A}(92.86 \%, \mathrm{~N}=26)$.

Among three 19 years Assamese Hindu Rh-negative students, two belonged to A blood group: Amid those Rhnegative students, two were female and one was male.

In that class there was 19 medical students, except one student (From Goa, ethnicity Konkani) all were from Assam. All local Muslim students showed Rh-positivity; B positive blood group was recoded on 8 cases followed by 0 positivity in 6 cases, $A$ and $A B$ positivity each in 2 cases.

\begin{tabular}{|c|c|c|c|c|}
\hline $\begin{array}{c}\text { Blood } \\
\text { Groups }\end{array}$ & $\begin{array}{c}\text { Total No. } \\
\text { (n=18) }\end{array}$ & Percentage & Male & Female \\
\hline A & 2 & 11.11 & 2 & 0 \\
\hline B & 8 & 44.44 & 5 & 3 \\
\hline AB & 2 & 11.11 & 2 & 0 \\
\hline O & 6 & 33.34 & 3 & 3 \\
\hline Table 2: Frequency Distribution of Different Blood \\
Groups among Assamese Muslim Medical Students \\
\hline
\end{tabular}

There were two Christian students with equal sex distribution and both were from Upper Assam. The 18 years male Christian student blood group was 0 positive and the 19 years female recorded 0 positive blood group.

\section{DISCUSSION}

Variables in ABO and Rh-D phenotypes are noted broadly across races and geographical boundaries. ${ }^{6}$ Limited studies on the prevalence of $\mathrm{ABO}$ and $\mathrm{Rh}$ blood groups have been conducted in the Indian population and common studies are limited to particular regions of the country. Very few such studies have yet been reported from North-East India.

In India, we have many types of ultra-rare phenotypes of blood groups like Bombay (Oh), -D-/-D-, in ( $\mathrm{a}+\mathrm{b}-$ ) Colton-null phenotype, CdE/CdE (ryry) phenotypes; those phenotypes are potential enough to pose problems in providing blood to the recipients having these phenotypes. ${ }^{7}$
The present study revealed among Assamese medical students, prevalence of blood group was $A>B>0>A B$. A study conducted by Talukdar et al. in the State of the Art Model Blood Bank, Gauhati, revealed blood group 0 was the commonest at $37.23 \%$ followed by blood groups B at $31.0 \%$, $A$ at $24.83 \%$ and $\mathrm{AB}$ at $6.93 \% .{ }^{8}$

Studies done in Northern parts of India by Chandra et al. at Lucknow and Sindhu et al. at Punjab showed blood group B was the commonest followed by $\mathrm{O}, \mathrm{A}$ and $\mathrm{AB}$. In Western Ahmedabad, Patel et al. carried a hospital-based study predominantly among male donors and reported the commonest ABO blood was B (39.40\%) followed by 0 (30.79\%), A (21.94\%) and $A B(7.86 \%)$. In this present study among students from Assam the most prevalent blood group was A (33.33\%) followed by B (30.95\%), O (25\%) and AB $(10.72 \%)$. A study done in Durgapur of West Bengal by Nag et al. found that commonest blood group was $\mathrm{O}$ followed by $\mathrm{B}, \mathrm{A}$ and $\mathrm{AB}$, dissimilar to our study. ${ }^{9,10,11,12}$

The present study pointed blood group A and B both were equal in distribution (12/37) (32.43\%) and the maximum prevalent blood group among the female study group followed by the AB blood group (27.03\%). Study done in North India by Chandra et al. displayed among female blood donors, the B positive blood group was most prevalent. ${ }^{9}$

A study carried on the distribution of blood groups among south Indian medical students of the Great Eastern Medical School, Andhra Pradesh, by Swamy et al. showed 0 was the commonest blood group in both sexes. But in this study among male students the commonest blood group was $\mathrm{A}$ and female students the maximum prevalent blood groups were A and B. 13

The Rhesus blood group is the most polymorphic and its medical implication in transfusion medicine is only next to the ABO blood group system. Multicentric study in India by Agrawal et al. revealed $94.61 \%$ of the donor population was $\mathrm{Rh}$ positive and the rest were Rh negative, similar to present study where $97.62 \%$ students were $\mathrm{Rh}$ positive and rest $2.38 \%$ were Rh negative. 
Study conducted by Parmanik et al. over Nepalese medical students, in Nepal Medical College, Kathmandu exhibited $96.66 \% \mathrm{Rh}$ positive cases which was consistent finding with our study. ${ }^{14,15}$

A study conducted by Hussain et al. among North Indian Muslim population highlighted the most frequent blood group was found to be group $029.97 \%$, followed by $A_{1} 26.52 \%$, B 20.03\%, $\mathrm{A}_{1} \mathrm{~B}$ 19.34\%, $\mathrm{A}_{2} 2.9 \%$ and $\mathrm{A}_{2} \mathrm{~B}$ 1.24\%. Meitei et al. in their study in Manipur showed high occurrence of blood group 0 among Muslim population and they assumed it is due to practice of consanguinity among the Muslims. The overall phenotypic frequencies of in the present study was $\mathrm{B}>\mathrm{O}>\mathrm{A}=\mathrm{AB} \cdot 16,17,18$

An epidemiological study in relation to Muslim and Christian communities of Kheda, Gujarat by Pant et al. showed blood group B was dominant in both the communities, but in present study among Christian students both $\mathrm{A}$ and $\mathrm{O}$ blood groups were prevalent. ${ }^{19}$

A study done over 152 medical students in Davangere, Karnataka by Hemlatha et al. published the most common blood group was $\mathrm{O}(41.5 \%)$ followed by B group (32.2\%), A group (19\%) and least being $A B$ group (7.2\%). Among the $\mathrm{Rh}$ blood group, $94 \%$ students were Rh positive, however only $6 \%$ were $\mathrm{Rh}$ negative. In this study among all one hundred medical students $\mathrm{A}, \mathrm{B}$ and $\mathrm{O}$ blood groups were seen in equal proportion, each in $30 \%$ cases and least being $A B$ group (10\%) and ninety seven percentage students were $\mathrm{Rh}$ positive. ${ }^{20}$

\section{CONCLUSION}

We noted that $\mathrm{ABO}$ and Rhesus ' $\mathrm{D}$ ' blood group distribution diverged in different parts of India. The study highlights similar frequency of distribution of $\mathrm{A}, \mathrm{B}$ and $\mathrm{O}$ blood group among students and $\mathrm{A}$ is the most prevalent blood group among Assamese population. Rhesus positive is much more common than Rhesus negative among Assamese population as well as in respect to Indian population. The knowledge of blood group distribution is important for clinical studies, for reliable geographical information and blood bank management. This study would help in developing Indiaspecific reagent cell-panels for antibody screening and identification, which would further aid in the improvement of transfusion services in the country.

\section{REFERENCES}

1. Garratty G, Dzik W, Issitt PD, et al. Terminology for blood group antigens and genes-historical origins and guidelines in the new millennium. Transfusion 2000;40(4):477-89.

2. Hillyer CD. Blood banking and transfusion medicinehistory, industry, and discipline. In: Shaz BH (ed) Transfusion medicine and hemostasis. Amsterdam: Elsevier, 2013;p 3-9.

3. Khurshid B, Naz M, Hassan M, et al. Frequency of ABO and $\mathrm{Rh}$ (D) blood groups in district swabi NWFP (Pakistan). J Sci Tech University Peshawar 1992;16:5-6.

4. Dar NJ, Srivastava A, Dar FA. Distribution of ABO blood groups and $\mathrm{Rh}(\mathrm{D})$ factor among the brahmin and kushwaha populations of Jhansi district UP. Nature Precedings 2011. doi:10:1038/npre.6362.1.
5. Racial and Ethnic Distribution of ABO Blood Types bloodbook.com, Blood information for life, 2006. http://www.bloodbook.com

6. Makroo RN. ABO blood group system. In: Makroo BN (ed.) Compendium of transfusion medicine. New Delhi: Kongposh Publications Pvt Ltd, 2009;p 42.

7. Joshi SR, Vasantha K. A profile of rare bloods in India and its impact in blood transfusion service. Asian J Transfus Sci 2012;6(1):42-3.

8. Talukdar L, Sarma U. Frequency of major blood group antigens among blood donors at a tertiary level hospital in North East India. IJSR 2014;3(9):2130-2.

9. Tulika C, Gupta A. Frequency of ABO and rhesus blood groups in blood donors. Asian J Transfus Sci 2012;6(1):52-3.

10. Sidhu S. Distribution of the ABO blood groups and Rh(D) factor among the scheduled caste population of Punjab. Anthropologist 2003;5(3):203-4.

11. Patel PA, Patel SP, Shah JV, et al. Frequency and distribution of blood groups in blood donors in Western Ahmedabad a hospital based study. Natl J Med Res 2012;2(2):202-6.

12. Nag I, Das SS. ABO and rhesus blood groups in potential blood donars at durgapur steel city of the district of Burdwan, West Bengal. Asian J Transfus Sci 2012;6(1):54-5.

13. Swamy GG, Chandrasekhar B, Parameswari J, et al. Frequency and distribution of blood groups among medical students of great eastern medical school, srikakulam, Andhra Pradesh, India. Int J Med Pharm Sci 2013;3(9):26-33.

14. Agrawal A, Tiwari AK, Mehta N, et al. ABO and Rh (D) group distribution and gene frequency; the first multicentric study in India. Asian J Transfus Sci 2014;8(2):121-5.

15. Parmanik T, Parmanik S. Distribution of $\mathrm{ABO}$ and $\mathrm{Rh}$ blood groups in Nepalese medical students: a report. East Mediterr Health J 2000;6(1):156-8.

16. Hussain R, Fareed M, Shah A, et al. Prevalence and gene frequencies of A1A2BO and Rh(D) blood group alleles among some muslim populations of North India. The Egyptian Journal of Medical Human Genetics 2013;14(1):69-76.

17. Meitei SM, Mohammad A, Achoubi ND, et al. Distribution of $\mathrm{ABO}$ and $\mathrm{Rh}(\mathrm{D})$ blood groups among four populations in Manipur, North East India. Anthropological notebooks 2000;16(2):19-28.

18. Bittles AH, Black ML. The impact of consanguinity on the Indian population. Indian Journal of Human Genetics 2002;8(2):45-51.

19. Pant CS, Gupta DK, Sharma RC, et al. Frequency of ABO blood groups, sickle-cell haemoglobin, G-6-PD deficiency and their relation with malaria in scheduled castes and scheduled tribes of Kheda district, Gujarat. Indian J Malariol 1992;29(4):235-9.

20. Hemalatha NR, Bhagya V. Frequency and distribution of blood groups among medical students in davanagere. J Pub Health Med Res 2015;3(1):1-4. 